\title{
PEMANFAATAN ABU TERBANG ( FLY ASH) BATU BARA SEBAGAI CAMPURAN PEMBUATAN BATA BETON
}

\author{
Haspiadi ${ }^{*}$
}

\begin{abstract}
The use of coal sources of energy has produce fly ashes, which has became a big source of pollution. Fly ash is a fine glass like powder recovered from gases created by coal fired electrical power generation. One of the alternatives to solve this problem is by using this material to produce paving block. This research was conducted to find possible use of fly ash to replace sand in paving block. In this research the effect of replacing zero to $40 \%$ sand with fly ash is evaluated. It is found out that best result could be obtained by replacing sand by $10 \%$ fly ash which meet the requirement according to National Standard of Indonesia SNI 03-0691-1996 Paving Block. The results of compression strength and surface area indicate that the requirement for parking area application (class B). On the other hand the result of water absorption analysis indicate the requirements of standard for garden place where garden plants, tools, etc are sold and other specification with the same level (class C).
\end{abstract}

Keywords : fly ash, sand, paving block, compression strength

\section{PENDAHULUAN}

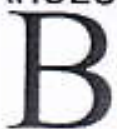

atubara sebagai salah satu bahan bakar yang banyak digunakan di industri berdasarkan data tahun 2005 memiliki cadangan yang cukup besar, khususnya di Kalimantan Timur dengan produksi batubara mencapai 87.351 juta ton (Anonim, 2008). Sehingga diperkirakan penggunaan bahan bakar batubara dapat menjamin pemenuhan kebutuhan bahan bakar di industri.

Pemanfaatan batubara dalam negeri umumnya digunakan di berbagai industri antara lain PLTU, industri semen, industri kertas, industri tekstil, industri metalurgi dan industri lainnya. PLTU merupakan industri yang paling banyak menggunakan batubara, tercatat dari seluruh konsumsi batubara dalam negeri pada tahun 2005 sebesar 35.342 juta ton, $71,11 \%$ diantaranya digunakan untuk PLTU. Hingga saat ini, jumlah PLTU berbahan bakar batubara, baik milik PLN maupun yang dikelola swasta ada sembilan buah dengan kapasitas sebesar $7550 \mathrm{MW}$ dan menggunakan batubara sekitar 25,1 juta ton per-tahun (Anonim, 2008).

Penggunaan batubara sebagai bahan bakar akan menghasilkan abu terbang ( $f l y$ ash) yang merupakan residu dari proses pembakaran pada pembangkit listrik. Dalam proses pembakaran abu terbang (fly ash) terlepas ke atmosfir lewat cerobong asap dan ditangkap dengan alat elektrostatik presipitator., Ukuran rata-rata abu terbang (fly ash) adalah 100-200 mesh ( 1 mesh = 1 lubang/inch2).

Secara mineralogi abu terbang tersusun dari fase gelas amorof, fasa kristalin dan komponen sekunder serta unsur-unsur jejak (trace element). Sedangkan secara kimia abu terbang terdiri dari kalcium, $\mathrm{CaO}(22,98 \%)$, silikon, $\mathrm{SiO} 2,(21.92 \%)$, besi, $\mathrm{Fe}_{2} \mathrm{O}_{3}(16,47 \%)$, aluminium, $\mathrm{Al}_{2} \mathrm{O}_{3}(16 \%)$, sulfur, $\mathrm{SO}_{3}(11,85 \%)$. magnesium, $\mathrm{MgO}(7,9 \%)$, sodium $\mathrm{Na}_{2} \mathrm{O}(1,37 \%)$, titanium $\mathrm{TiO}_{2}$ $(0,6 \%)$, mangan, $\mathrm{Mn}_{3} \mathrm{O}_{4}(0,18 \%)$ dan fosfor $\mathrm{P}_{2} \mathrm{O}_{5}(0,11 \%)$.

Berdasarkan komposisi kimia abu terbang (fly ash) secara spesifik dapat digunakan sebagai komponen penyusun bahan bangunan. Oleh karena itu dalam penelitian ini telah dilakukan percobaan memanfaatkan abu terbang (fly ash) sebagai campuran pembuatan bata beton untuk 
mensubtitusi pasir. Diharapkan dengan pemanfaatan ini dapat memberi nilai tambah abu terbang sekaligus memberi solusi dalam penanganan limbah padat abu terbang (fly ash) yang dihasilkan dari setiap proses penggunaan bahan bakar batubara.

\section{BAHAN DAN METODE \\ Bahan dan Peralatan}

Bahan yang yang digunakan dalam penelitian ini adalah : semen portland, pasir yang diambil di Sungai Mahakam dan abu terbang (fly ash) yang diambil dari Pembangkit Listrik di PT. Sumalindo Lesatari Jaya MDF di Senoni Kutai Kartanegara. Sedangkan jenis peralatan yang digunakan antara lain ; satu unit alat cetakan bata beton, ayakan, timbangan, sendok semen, sekop, tangki perendaman volume 50 liter, alat penakar (ember plastik), wadah pencampur manual, oven, dan alat ukur kuat tekan (tensile stength).

\section{Metode}

Penelitian diawali dengan pengambilan sampel penelitian abu terbang ( $f l y$ ash) di unit pembangkit listrik berbahan bakar batubara di PT. Sumalindo Lestari Jaya MDF. Kemudian dilakukan analisa kimia dan fisika abu terbang untuk mengetahui sifat dan komposisi dominan penyusun abu terbang terkait kebutuhan untuk pembuatan bata beton, serta uji The Toxicity Charactersitics Leaching Prosedure (TCLP) dengan metode USEPA 1131 TCLP untuk mengetahui sifat toksisitas abu terbang terkait sifatnya sebagai limbah padat. Selanjutnya dilakukan percobaan pembuatan bata beton dari campuran abu terbang (fly ash) dengan komposisi $1: 6,1: 8,1: 10,1$ : 12 bagian semen dan pasir serta $0 \%, 10 \%, 20 \%$, dan $40 \%$ abu terbang terhadap jumlah pasir dan terkahir pengujian mutu bata beton hasil percobaan.

\section{a. Pengujian}

Pengujian abu terbang (fly ash) untuk komposisi kimia meliputi : silaka oksida $\left(\mathrm{SIO}_{2}\right)$, aluminium oksida $\left(\mathrm{Al}_{2} \mathrm{O}_{3}\right)$, besi oksida $\left(\mathrm{Fe}_{2} \mathrm{O}_{3}\right)$, kalsium oksida $(\mathrm{CaO})$, magnesium oksida $(\mathrm{MgO})$, natrium dioksida $\left(\mathrm{Na}_{2} \mathrm{O}\right)$, kalium dioksida $\left(\mathrm{K}_{2} \mathrm{O}\right)$, mangan oksida $(\mathrm{MgO})$, titan oksida $\left(\mathrm{TiO}_{2}\right)$, fosfat $\left(\mathrm{P}_{2} \mathrm{O}_{3}\right)$, sulfit $\left(\mathrm{SO}_{3}\right)$ dan $\mathrm{pH}$. Untuk pengujian fisika meliputi warna abu terbang, berat jenis dan ukuran partikel. Sedangkan untuk uji TCLP mengikuti parameter yang diatur oleh Peraturan Pemerintah No. 85 tahun 1999, tentang: Perubahan Atas Peraturan Pemerintah No. 18 tahun 1999, tentang: Pengelolaan Limbah Bahan Berbahaya dan Beracun.

b. Proses Pembuatan

Adapun tahapan pembuatan bata beton adalah sebagai berikut:

1. Bahan pembuatan bata beton yaitu pasir dibebaskan dari kotoran serta benda-benda organis lainnya. Kehalusan pasir antara $3,7,4,3 \mathrm{~mm}$;

2. Masing-masing 1 (satu) bagian semen, 6 (enam), 8 (delapan), 10 (sepuluh) dan 12 (duabelas) bagian pasir, serta $0 \%$ (kontrol), $10 \%, 20 \%$, dan $40 \%$ abu terbang (fly ash) terhadap pasir dicampur dan diaduk hingga benar-benar homogen sampai tercapai campuran setengah basah (lengas tanah) yang merata. Secara sederhana dapat diketahui dengan cara : campuran yang telah merata dikepal dengan telapak tangan. Kemudian dijatuhkan dari ketinggian lebih kurang 1,2 meter kepermukaan tanah keras. Bila campuran sudah baik, 2/3 bagian tetap mengumpul dan $1 / 3$ lainnya tersebar.

3. Kemudian pencetakan, dimana campuran yang sudah jadi dimasukkan ke dalam cetakan sedikit demi sedikit sambil dipadatkan dengan penumbukan;

4. Pembukaan cetakan dilakukan dengan hati-hati dan perlahan-lahan untuk menghindari kerusakan-kerusakan dan ketidak sempurnaan bentuk maupun sudut-sudutnya dan dibiarkan pada posisi tersebut selama kurang lebih 24 jam;

5. Pengeringan lanjutan dilakukan dengan angin dalam waktu 3 minggu dalam posisi tersusun dan tertumpuk.

\section{HASIL DAN PEMBAHASAN \\ Hasil Uji Abu Terbang (Fly Ash)}

A,bu terbang (fly ash) disebut pula dengan pozzolonic material karena kandungan silika oksida $\left(\mathrm{SiO}_{2}\right)$, besi oksida $\left(\mathrm{Fe}_{2} \mathrm{O}_{3}\right)$ aluminium oksida $\left(\mathrm{Al}_{2} \mathrm{O}_{3}\right)$, kalsium oksida $(\mathrm{CaO})$ dan magnesium oksida (MgO) yang cukup tinggi sebagaimana hasil uji dari abu terbang yang digunakan dalam peneltian pada Tabel 1. 
Tabel 1. Karakteristik Kimia-Fisika Abu Terbang yang Digunakan Dalam Penelitian

\begin{tabular}{|c|c|c|}
\hline Parameter & Satuan & Hasil Uji \\
\hline $\mathrm{SiO}_{2}$ & $\%$ adbk & 55,40 \\
\hline $\mathrm{Al}_{2} \mathrm{O}_{3}$ & $\%$ adbk & 13,67 \\
\hline $\mathrm{Fe}_{2} \mathrm{O}_{3}$ & $\%$ adbk & 8,78 \\
\hline $\mathrm{CaO}$ & $\%$ adbk & 14,76 \\
\hline $\mathrm{MgO}$ & $\%$ adbk & 1,01 \\
\hline $\mathrm{Na}_{2} \mathrm{O}$ & $\%$ adbk & 0,25 \\
\hline $\mathrm{K}_{2} \mathrm{O}$ & $\%$ adbk & 1,17 \\
\hline $\mathrm{MnO}_{2}$ & $\%$ adbk & 0,16 \\
\hline $\mathrm{TiO}_{2}$ & $\%$ adbk & 1,02 \\
\hline $\mathrm{P}_{2} \mathrm{O}_{5}$ & $\%$ adbk & 0,27 \\
\hline $\mathrm{SO}_{3}$ & $\%$ adbk & 0,74 \\
\hline $\mathrm{pH}$ & - & 7,08 \\
\hline Warna & - & Putih ke abu-abuan \\
\hline Berat Jenis & - & 1,6 \\
\hline Ukuran Partikel & $\mu \mathrm{m}$ & $\leq 75$ \\
\hline
\end{tabular}

Hasil uji komposisi kimia abu terbang (fly ash) yang digunakan dalam penelitian ini meliputi $\mathrm{SiO}_{2}$ yaitu $55,40 \%$ cukup tinggi dibandingkan rata-rata kandungan $\mathrm{SiO}_{2}$ dalam abu terbang yaitu sebesar $52,00 \%$. Demikian pula dengan $\mathrm{Al}_{2} \mathrm{O}_{3}$ sebesar $13,67 \%$ dimana berada pada kisaran kandungan $\mathrm{Al}_{2} \mathrm{O}_{3}$ jenis abu terbang dari batubara bituminous (sumber PJB Paiton). Adanya proses karbonisasi dalam pembakaran batubara menyebabkan silika dioksida atau dikenal dengan silox dan aluminium oksida atau dikenal dengan alumina dalam abu terbang batubara meningkat. Sehingga abu terbang di beberapa industri semen banyak dimanfaatkan sebagai sumber silika dan alumina dalam proses pembuatan semen.

Secara kimia abu batubara hasil pembakaran yang merupakan material oksida organik dengan kandungan silika dan alumina aktif dapat bereaksi dengan komponen lain membentuk interface yang lebih sempurna. Menurut Sugiri. S. 2005, bahwa dengan kandungan silika yang tinggi proses hidrasi yang terjadi antara pasta semen dan agregat membentuk interface yang lebih sempurna sehingga kehancuran beton tidak mudah terjadi.

Selain kandungan $\mathrm{SiO}_{2}$ dan $\mathrm{Al}_{2} \mathrm{O}_{3}$, hasil uji kandungan $\mathrm{Na}_{2} \mathrm{O}$ dalam abu terbang sebesar $0,25 \%$ serta kandungan $\mathrm{K}_{2} \mathrm{O}$ dalam abu terbang sebesar 1,17 juga cukup tinggi. Dalam pembuatan keramik bila white clay mengandung banyak fluks $\left(\mathrm{Na}_{2} \mathrm{O}\right.$ dan $\left.\mathrm{K}_{2} \mathrm{O}\right)$ akan memiliki sifat keplastisitasan artinya kemampuan untuk dibentuk tanpa mudah menjadi retak (Anonim, 1998). Sifat ini dapat mempengaruhi kualitas bata beton.

Demikian pula hasil uji kandungan MgO dalam abu terbang sebesar 1,01\% dimana dalam proses pembuatan semen akan mempengaruhi penampakan dari campuran semen yang licin (Anonim, 1998). Sedangkan untuk kandungan $\mathrm{CaO}$ yang cukup tinggi dalam abu terbang sebesar $14,76 \%$ cukup baik untuk campuran pembuatan bata beton di daerah dengan kondisi tanah yang asam, dimana dengan adanya $\mathrm{CaO}$ bila bereaksi dengan air $\left(\mathrm{H}_{2} \mathrm{O}\right)$ menghasilkan kalsium hidroksida $\left[\mathrm{Ca}(\mathrm{OH})_{2}\right]$ yang bersifat basa, sifat ini diperlukan dalam pembuatan semen tahan asam.

Sebagaiman dengan uji komposisi kimia juga dilakukan uji sifat fisik abu terbang yang meliputi warna, berat jenis dan ukuran partikel. Berat jenis abu terbang (fly ash) sebesar 1,6, sedangkan warna abu terbang putih keabu-abuan dan untuk ukuran partikel abu terbang yang digunakan dalam peneltian ini rata-rata $\leq 75 \mu \mathrm{m}$. Selain analisa komposisi kimia-fisika dari abu terbang (fly ash) juga dilakukan analisa toksisitas dengan uji TCLP (The Toxicity Charactersitics dalaching Prosedure). Pengujian ini dimaksudkan untuk mengetahui kadar atau konsentrasi unsur logam berat utama yang dikategorikan dominan dari fly ash seperti selenium (Se), kromium (Cr) 
Berdasarkan Peraturan Pemerintah No. 85 tahun 1999, tentang: Perubahan Atas Peraturan Pemerintah No. 18 tahun 1999, tentang : Pengelolaan Limbah Bahan Berbahaya dan Beracun semua parameter uji TCLP dalam abu terbang yang digunakan dalam penelitian ini, hasil uji dengan metode USEPA 1131 TCLP masih jauh di bawah batas yang dipersyaratkan sebagaimana pada Tabel 2 .

Tabel 2. Hasil Uji TCLP Abu Terbang (Fly Ash) Batubara yang Digunakan dalam Penelitian

\begin{tabular}{|c|c|c|c|}
\hline Parameter & Satuan & Fly Ash & $\begin{array}{c}\text { Baku Mutu TCLP } \\
\text { (Hasil ekstraksi/Lindi),mg/L }\end{array}$ \\
\hline Perak, Ag & $\mathrm{mg} / \mathrm{L}$ & $<0,001$ & - \\
\hline Kadmium,Cd & $\mathrm{mg} / \mathrm{L}$ & $<0,001$ & 1 \\
\hline Kobalt, Co & $\mathrm{mg} / \mathrm{L}$ & 0,056 & - \\
\hline Tembaga, $\mathrm{Cu}$ & $\mathrm{mg} / \mathrm{L}$ & $<0,001$ & 10 \\
\hline Timbal, $\mathrm{Pb}$ & $\mathrm{mg} / \mathrm{L}$ & $<0,005$ & 0,5 \\
\hline Seng, $\mathrm{Zn}$ & $\mathrm{mg} / \mathrm{L}$ & 1,09 & 50 \\
\hline Nikel, Ni & $\mathrm{mg} / \mathrm{L}$ & 0,089 & - \\
\hline Besi, Fe & $\mathrm{mg} / \mathrm{L}$ & 0,026 & - \\
\hline Mangan, Mn & $\mathrm{mg} / \mathrm{L}$ & 1,87 & - \\
\hline Kromium, $\mathrm{Cr}$ & $\mathrm{mg} / \mathrm{L}$ & $<0,002$ & 5 \\
\hline Kalium, K & $\mathrm{mg} / \mathrm{L}$ & 2,86 & - \\
\hline Natrium, $\mathrm{Na}$ & $\mathrm{mg} / \mathrm{L}$ & $<0,005$ & - \\
\hline Molebdium, Mo & $\mathrm{mg} / \mathrm{L}$ & $<0,1$ & - \\
\hline Aluminium, $\mathrm{Al}$ & $\mathrm{mg} / \mathrm{L}$ & 0,9 & - \\
\hline Kalsium, $\mathrm{Ca}$ & $\mathrm{mg} / \mathrm{L}$ & 144 & - \\
\hline Magnesium, Mgl & $\mathrm{mg} / \mathrm{L}$ & 34,4 & - \\
\hline Raksa, $\mathrm{Hg}$ & $\mathrm{mg} / \mathrm{L}$ & $<0,0003$ & 0,2 \\
\hline Arsen, As & $\mathrm{mg} / \mathrm{L}$ & $<0,001$ & 5 \\
\hline Bismut, Bi & $\mathrm{mg} / \mathrm{L}$ & $<0,003$ & - \\
\hline Antimon,Sb & $\mathrm{mg} / \mathrm{L}$ & $<0,001$ & - \\
\hline Selenium, Se & $\mathrm{mg} / \mathrm{L}$ & $<0,001$ & 1 \\
\hline Timah, Sn & $\mathrm{mg} / \mathrm{L}$ & $<0,001$ & - \\
\hline Telerium, Te & $\mathrm{mg} / \mathrm{L}$ & $<0,001$ & - \\
\hline Boron, B & $\mathrm{mg} / \mathrm{L}$ & 13,1 & 500 \\
\hline
\end{tabular}

Khusus konsentrasi logam-logam berat seperti parameter perak (Ag), kadmium (Cd), timbal $(\mathrm{Pb})$, kromium ( $\mathrm{Cr}$ ), Raksa $(\mathrm{Hg})$, Arsen ( $\mathrm{As}$ ) dan selenium (Se) yang terkandung dalam abu terbang hasil uji lebih kecil dari kemampuan minimal deteksi alat. Demikian pula dengan parameter tembaga masih dibawah batas deteksi minimal alat. Hal yang sama juga untuk kandungan boron (B) masih dibawah baku mutu.

Beberapa parameter yang tidak diatur dalam Peraturan Pemerintah No 85 tahun 1999 karena sifat unsur tersebut yang berbahaya maka tetap dilakukan pula pengujian Kandungan unsurunsur tersebut bila dibandingkan dengan umumnya yang terdapat dalam lapisan bumi masih lebih kecil sebagai contoh kadmium (Cd) sebesar $0,0001 \mathrm{~g} / \mathrm{Kg}$, timbal $(\mathrm{Pb}) 0,0125 \mathrm{~g} / \mathrm{Kg}$, $\mathrm{kromium}(\mathrm{Cr})$ $0,1 \mathrm{~g} / \mathrm{Kg}$, merkuri $(\mathrm{Hg}) 8 \times 10^{-5} \mathrm{~g} / \mathrm{Kg}$, Arsen (As) $0,0018 \mathrm{~g} / \mathrm{Kg}$ dan selenium (Se) $5 \times 10^{-5} \mathrm{~g} / \mathrm{Kg}$ (Anonim, 1999). Atas dasar analisa TCLP tersebut, selanjutnya fly asah dimanfaatkan sebagai substitusi pasir dalam pembutan bata beton.

Berdasarkan komposisi kimia abu terbang yang kaya akan senyawa yang diperlukan dalam pembuatan bahan bangunan termasuk untuk pembuatan bata beton serta sifat fisik yang dimiliki, serta didukung oleh data hasil uji TCLP (The Toxicity Charactersitics Leaching Prosedure) yang memberikan gambaran kandungan bahan-bahan yang merupakan komposisi limbah padat kategori limbah B3, maka atas dasar itu abu terbang tersebut dalam penelitian ini dicoba untuk 
dimanfaatkan sebagai campuran pembuatan bata beton.

\section{Karakteristik Bata Beton Menggunakan Campuran Abu Terbang (Fly Ash)}

Pembuatan bata beton dari campuran Abu terbang (fly ash), semen dan pasir dengan komposisi sebagaimana pada Tabel 3 dihasilkan bata beton dengan berbagai mutu mengacu pada Standar Nasional Indonesia SNI 03-0691-1996, tentang Bata beton (Paving Block)

\section{a.Kuat Tekan Bata beton (Paving Block)}

Kuat tekan adalah besarnya beban persatuan luas yang menyebabkan benda uji hancur bila dibebani dengan gaya tekan tertentu, yang dihasilkan oleh mesin tekan. Hasil uji kuat tekan bata beton (paving block) campuran Abu terbang (fly ash) setelah umur 21 hari sebagaimana tertera pada Tabel 3.

Tabel 3. Kuat Tekan Bata Beton Campuran Fly Ash, Semen dan Pasir

\begin{tabular}{|c|c|c|c|c|c|c|c|}
\hline \multirow{2}{*}{ Kode } & \multicolumn{2}{|c|}{ Komposisi } & \multicolumn{2}{|c|}{$\begin{array}{l}\text { Hasil Uji Kuat } \\
\text { Tekan (Mpa) }\end{array}$} & \multicolumn{2}{|c|}{ Syarat Mutu } & \multirow{2}{*}{ Mutu } \\
\hline & $\begin{array}{l}\text { Semen: } \\
\text { Pasir }\end{array}$ & Fly Ash & Rata-rata & Min. & Rata-rata & Min. & \\
\hline $\mathrm{Ct} 1$ & $1: 6$ & $0 \%$ & 30 & 29 & 20 & 17,0 & $B$ \\
\hline $\mathrm{Ct} 2$ & $1: 8$ & $0 \%$ & 27 & 26 & 20 & 17,0 & B \\
\hline $\mathrm{Ct} 3$ & $1: 10$ & $0 \%$ & 26 & 23 & 20 & 17,0 & B \\
\hline $\mathrm{Ct} 4$ & $1: 12$ & $0 \%$ & 22 & 19 & 20 & 17,0 & B \\
\hline $\mathrm{A} 1$ & $1: 6$ & $10 \%(0,6)$ & 26 & 25 & 20 & 17,0 & $B$ \\
\hline $\mathrm{A} 2$ & $1: 8$ & $10 \%(0,8)$ & 18 & 17 & 15 & 12,5 & C \\
\hline $\mathrm{A} 3$ & $1: 10$ & $10 \%(1)$ & 20 & 19 & 20 & 17,0 & $B$ \\
\hline A4 & $1: 12$ & $10 \%(1,2)$ & 12 & 11 & 10 & 8,5 & D \\
\hline B1 & $1: 6$ & $20 \%(1,2)$ & 18 & 17 & 15 & 12,5 & C \\
\hline B2 & $1: 8$ & $20 \%(1,6)$ & 17 & 16 & 15 & 12,5 & C \\
\hline B3 & $1: 10$ & $20 \%(2)$ & 18 & 17 & 15 & 12,5 & C \\
\hline B4 & $1: 12$ & $20 \%(2,4)$ & 17 & 17 & 15 & 12,5 & C \\
\hline $\mathrm{C} 1$ & $1: 6$ & $40 \%(2,4)$ & 17 & 16 & 15 & 12,5 & C \\
\hline $\mathrm{C} 2$ & $1: 8$ & $40 \%(3,2)$ & 16 & 15 & 15 & 12,5 & C \\
\hline $\mathrm{C} 3$ & $1: 10$ & $40 \%(4)$ & 17 & 16 & 15 & 12,5 & $\mathrm{C}$ \\
\hline $\mathrm{C} 4$ & $1: 12$ & $40 \%(4,8)$ & 14 & 13 & 10 & 8,5 & D \\
\hline
\end{tabular}

Mutu kuat tekan bata beton berdasarkan hasil uji bervariasi dan untuk bata beton dengan penambahan abu terbang $10 \%, 20 \%$ dan $40 \%$ umumnya memiliki mutu di bawah dari bata beton yang dibuat tanpa penambahan abu terbang kecuali penggunaan abu terbang $10 \%$ yang mensusbtitusi pasir dengan perbandingan 1:6 dan $1: 10$. Untuk perlakuan dengan tanpa penambahan abu terbang abu terbang mutu bata beton berdasarkan kuat tekan masuk dalam mutu $B$ yang peruntukannya dapat digunakan untuk pelataran parkir.

Bata beton dengan penambahan abu terbang $10 \%$ untuk komposisi $1: 6$ dan $1: 10$ memenuhi mutu $B$, sedangkan untuk campuran dengan komposisi 1:6, 1:8, 1: 10 dan 1:12 menggunakan $20 \%$ abu terbang serta komposisi $1: 6,1: 8,1: 10$ dan $1: 12$ menggunakan $40 \%$ abu terbang memenuhi mutu $\mathrm{C}$ artinya mutu yang sesuai untuk penggunaan peruntukan pejalan kaki. Demikian pula sampel dengan komposisi $1: 8$ untuk $10 \%$ abu terbang masuk dalam mutu $\mathrm{C}$. Sedangkan untuk $10 \%$ abu terbang dengan komposisi $1: 12$ masuk dalam mutu $D$ yaitu mutu untuk peruntukan taman dan penggunaan lain yang setara. Untuk lebih jelasnya dapat dilihat grafik pada Gambar 1. 


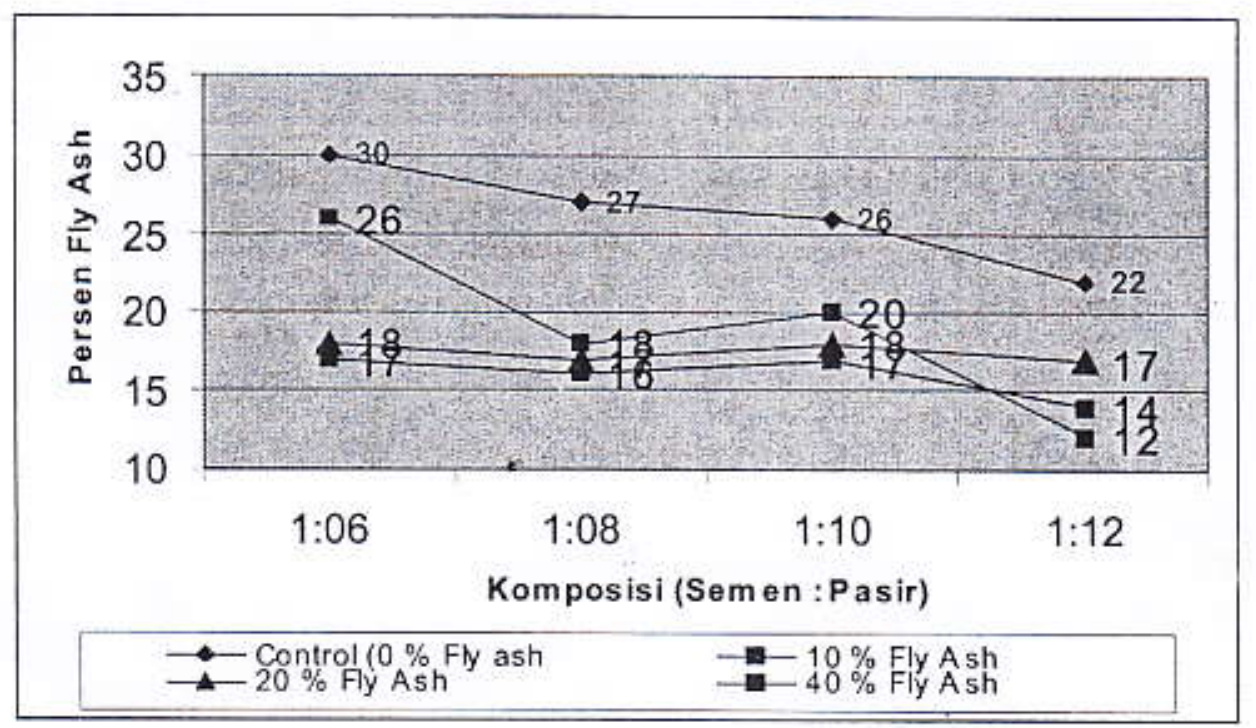

Gambar 1. Grafik Kuat Tekan Bata Beton Menggunakan Abu Terbang (Fly Ash)

Berdasarkan peruntukan penggunaan, maka mutu bata beton (paving block) sesuai SNI 03-0691-1996 Bata beton (Paving Block), umumnya masuk dalam mutu C yaitu peruntukannya lebih ringan dari tanpa penggunaan abu terbang, khususnya untuk penggunaan abu terbang $20 \%$ dan $40 \%$ dengan komposisi masing-masing $1: 6,1: 8,1: 10$ dan $1: 12$ serta $10 \%$ dengan komposisi $1: 8$ dan $1: 12$

Lebih rendahnya kuat tekan yang dihasilkan oleh bata beton dengan penambahan abu terbang dibandingkan tanpa penambahan abu terbang bila dilihat dari berat rata-rata setiap formula yang menurun, dapat dimungkinkan oleh pengaruh bobot jenis dari abu terbang yang kecil yaitu 1,6 yang mensubtitusi pasir dengan bobot jenis 2,56 . Dari pengamatan yang dilakukan secara fisik bahwa berat jenis yang kecil dapat mempengaruhi keseragaman adukan sehingga turut mempengaruhi kekompakan adukan yang pada akhirnya kuat tekan menjadi kecil pula. Demikian pula menurut Yoga. P., et.al. 2007 bahwa abu terbang batubara yang berbentuk bola padat banyak memiliki rongga.

Walaupun bila dilihat dari kandungan silika dan alumina yang cukup tinggi dalam abu terbang yang digunakan pada peneltian ini, namun tidak memberikan dampak terhadap kekuatan bata beton sebagaimana teori yang disebutkan bahwa tingginya silika dan alumina akan membentuk proses hidrasi yang terjadi antara pasta semen dan agregat membentuk interface yang lebih sempurna sehingga kehancuran beton tidak mudah terjadi (Sugiri S., 2005). Hal ini dapat dimungkinkan oleh jumlah semen yang digunakan cukup kecil yaitu 1 bagian saja dibandingkan jumlah pasir yang lebih banyak sehingga proses hidrasi membentuk interface antara silika dan alumina dalam abu terbang dengan pasta semen tidak optimal. Selain itu pula homogenisasi campuran saat pengadukan dapat mempengaruhi kekompakan campuran antara semen, pasir dan abu terbang.

\section{a. Penyerapan Air}

Penyerapan air dihitung berdasarkan persentase jumlah air yang terserap oleh benda uji hingga jenuh ( $24 \mathrm{jam}$ ) dan ditimbang dalam keadaan basah. Hasil uji penyerapan air bata beton dapat dilihat pada Tabel 4. 
Tabel 4. Penyerapan Air dan Sifat Tampak Bata Beton Menggunakan Campuran Abu Terbang, Pasir dan Semen

\begin{tabular}{|c|c|c|c|c|c|c|}
\hline \multirow{2}{*}{ Kode } & \multicolumn{2}{|c|}{ Komposisi } & \multicolumn{2}{c|}{$\begin{array}{c}\text { Penyerapan Air } \\
\text { Rata-rata (maks.) }\end{array}$} & $\begin{array}{c}\text { Berat } \\
\text { rata-rata } \\
\text { kering (g) }\end{array}$ & $\begin{array}{c}\text { Sifat } \\
\text { tampak }\end{array}$ \\
\cline { 2 - 5 } & $\begin{array}{c}\text { Semen: } \\
\text { Pasir }\end{array}$ & Fly Ash & $\begin{array}{c}\text { Hasil } \\
\text { Uji }(\%)\end{array}$ & $\begin{array}{c}\text { Syarat } \\
\text { Mutu (\%) }\end{array}$ & & \\
\hline Ct1 & $1: 6$ & $0 \%$ & 5,6 & B & 2667 & Baik \\
\hline Ct2 & $1: 8$ & $0 \%$ & 6,0 & B & 2669 & Baik \\
\hline Ct3 & $1: 10$ & $0 \%$ & 6,0 & B & 2699 & Baik \\
\hline Ct4 & $1: 12$ & $0 \%$ & 6,0 & B & 2753 & Baik \\
\hline A1 & $1: 6$ & $10 \%(0,6)$ & 7,8 & B & 2400 & Baik \\
\hline A2 & $1: 8$ & $10 \%(0,8)$ & 7,2 & C & 2447 & Baik \\
\hline A3 & $1: 10$ & $10 \%(1)$ & 7,9 & C & 2425 & Baik \\
\hline A4 & $1: 12$ & $10 \%(1,2)$ & 7,3 & C & 2200 & Baik \\
\hline B1 & $1: 6$ & $20 \%(1,2)$ & 8,0 & C & 2209 & Baik \\
\hline B2 & $1: 8$ & $20 \%(1,6)$ & 8,0 & C & 2099 & Baik \\
\hline B3 & $1: 10$ & $20 \%(2)$ & 7,8 & C & 2038 & Baik \\
\hline B4 & $1: 12$ & $20 \%(2,4)$ & 8,8 & C & 1943 & Baik \\
\hline C1 & $1: 6$ & $40 \%(2,4)$ & 8,4 & D & 1617 & Baik \\
\hline C2 & $1: 8$ & $40 \%(3,2)$ & 8,8 & D & 1319 & Baik \\
\hline C3 & $1: 10$ & $40 \%(4)$ & 8,7 & D & 1591 & Baik \\
\hline C4 & $1: 12$ & $40 \%(4,8)$ & 8,9 & D & 1552 & Baik \\
\hline
\end{tabular}

Hasil uji penyerapan air bata beton menggunakan campuran abu terbang menunjukkan adanya kenaikan dengan naiknya persen penambahan abu terbang. Untuk penambahan $10 \%$ dengan komposisi $1: 6,1: 8,1: 10$ dan $1: 12$ (semen dan pasir) semuanya di atas dari persen penyerapan air tanpa adanya penambahan abu terbang dan masuk dalam tipe $\mathrm{C}$ yang mempersyaratkan penyerapan air maksimum $8 \%$.

Sama halnya dengan penambahan $20 \%$ abu terbang, dengan komposisi $1: 6,1: 8$ dan $1: 10$ masuk dalam tipe $C$, sedangkan untuk komposisi 1 : 12 nilai persen penyerapan air sebesar $8,8 \%$ masuk dalam mutu $\mathrm{D}$ yang mempersyaratkan penyerapan air maksimum $10 \%$, yaitu bata beton peruntukan untuk pejalan kaki. Berbeda dengan penambahan $10 \%$ untuk komposisi 1:6, 1:8 1:10 dan 1:12 dengan $40 \%$ abu terbang persen penyerapan air semuanya tinggi diatas rata-rata penggunaan abu terbang $10 \%$ dan $20 \%$.

Tingginya persentase penyerapan air oleh bata beton dengan kenaikan jumlah penggunaan abu terbang dapat disebabkan oleh pori dalam struktur bata beton. Penyebab lain dapat disebabkan oleh adanya proses pembakaran menyebabkan pori-pori dari partikel abu terbang akan terbuka, sehingga abu terbang yang mengisi ruang pada bata beton akan semakin kuat menyerap air dalam jumlah volume yang besar sebagaimana pada Gambar 2.

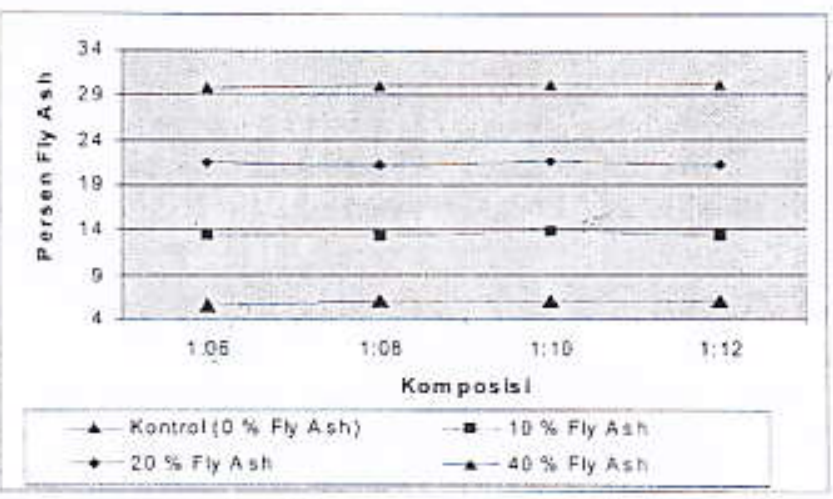

Gambar 2. Grafik Persen Penyerapan Air Bata Beton Menggunakan Abu Terbang (Fly Ash) 


\section{Sifat Tampak}

Sifat tampak sesuai SNI 03-0691-1996, Bata beton (paving block) dilihat secara visual dengan indikator permukaan yang rata dan tidak terdapat retak-retak dan cacat bagian sudut serta rusuknya tidak mudah direpihkan dengan kekuatan jari tangan. Secara umum bata beton masuk dalam kategori baik. Berdasarkan komposisi kimia abu terbang sifat ini dapat disebabkan oleh kandungan $\mathrm{MgO}$ sebesar 1,01\% sebagaimana teori dalam proses pembuatan semen kandungan $\mathrm{MgO}$ akan mempengaruhi penampakan dari campuran semen dengan agregat yang licin (Anonim, 1998).

Demikian $\mathrm{pu} \mathrm{l}$ a dengan kandungan $\mathrm{Na}_{2} \mathrm{O}$ dalam abu terbang sebesar $0,25 \%$ serta kandungan $\mathrm{K}_{2} \mathrm{O}$ dalam abu terbang sebesar $1,17 \%$ yang dapat menyebabkan keplastisitasan. Jika dibandingkan dengan tanpa penambahan abu terbang, maka bata beton yang menggunakan abu terbang memiliki permukaan yang halus dimana pori yang terbentuk tertutup oleh partkel abu batubara yang berdiameter halus.

\section{Spesifikasi Bata Beton Hasil Percobaan}

Secara umum spesifikasi teknis bata beton terbaik mengacu pada SNI 03-0691-1996, Bata beton (paving block), yang dibuat dari campuran abu terbang (fly ash ), dengan formula Semen : Pasir 1:6 (jumlah abu terbang yang digunakan $10 \%$ dari jumlah pasir) sebagaimana pada tabel 5 .

Tabel 5. Spesifikasi Bata Beton dari Campuran Fly Ash yang terbaik dari Percobaan

\begin{tabular}{|c|l|c|c|c|c|c|c|}
\hline \multirow{2}{*}{ No } & \multirow{2}{*}{$\begin{array}{c}\text { Parameter } \\
\text { Uji }\end{array}$} & \multirow{2}{*}{ Satuan } & \multicolumn{2}{|c|}{ Hasil Uji } & \multicolumn{2}{|c|}{ Syarat Mutu } & \multirow{2}{*}{$\begin{array}{c}\text { Tipe Sesuai } \\
\text { Syarat } \\
\text { Mutu }\end{array}$} \\
\cline { 4 - 7 } & & Rata-rata & Min. & Rata-rata & Min. & B \\
\hline 1 & Kuat tekan & Mpa & 26 & 25 & 20 & 17,0 & B \\
\hline 2 & Penyerapan air & $\%$ & \multicolumn{2}{|c|}{7,8} & \multicolumn{2}{c|}{ Rata-rata maks. 8 } & C \\
\hline 3 & Sifat tampak & - & \multicolumn{2}{|c|}{ Baik } & \multicolumn{2}{|c|}{ Baik } & B \\
\hline
\end{tabular}

Catatan:

$B \quad=$ Mutu yang mempersyaratkan bata beton untuk pelataran parkir

$\mathrm{C}$ = Mutuyang mempersyaratkan bata beton peruntukan taman dan penggunaan lain yang setara.

Baik = Tidak terdapat retakan dan tidak muda direpihkan

\section{KESIMPULAN}

Abu terbang ( $f l y$ ash) dalam penanganannya dapat digunakan sebagai substitusi pasir untuk campuran pembuatan bata beton. Hasil uji terbaik mengikuti komposisi yang umum digunakan aualah campuran semen dan pasir $1 ; 6$ dengan $10 \%$ fly ash berdasarkan kuat tekan dan sifat tampak memenuhi syarat mutu B sesuai SNI 03-0691-1996, Bata beton (paving block) dan daya serap air masuk mutu $C$.

Mutu bata beton yang masih memungkinkan untuk ditingkakan ke mutu A dengan kuat tekan rata-rata $40 \mathrm{Mpa}$ dan persen penyerapan air maksimum $3 \%$ maka perlu diperhatikan keseragaman campuran, perbandingan komposisi bahan baku antara semen dan pasir, serta tekanan pencetakan yang lebih besar serta tingkat pengabuan dari abu terbang (fly ash) tersebut yang lebih sempurna.

\section{DAFTAR PUSTAKA}

Anonim, 1998. Proses Industri Kimial. Materi Pelajaran PEDC Bandung, Edisi 1998

Anonim (1999). Environmental Chemistry. Course Details Lecture Notes, Departemen of Chemistry. The University of Queensland.

Anonim 2000. Coal Bottom Ash/ Boiler Slag-Material Description (http://WWW.cedar.at/mailarchives/waste/abahsi.htm. Diakses pada tanggal 17 Mei 2008. 
Anonim (2008). Fly-Bottom Ash dan Pemanfaatannya. http://b3.menlh.go.id/3r/article.php/articel_id. Diakses pada tanggal 18 Februari 2008 DSN 1996. Standar Nasional Indonesia (SNI) 03-0691-1996. Bata Beton (Paving Block). Dewan
Standardisasi Nasional, Jakarta.

Evangelou. V.P., 2007. Coal Ash Chemical Properties and Potential Influence on Water Quality. Agronomy Departement. University of Kentucky, Lexington, Kentucy.

Moulton Lyle K. Bottom Ash and Boiler Slag, Proceding of The Third International Ash Utilization Symposium. U.S. Bureau of Mines Information Circular No. 8640, Whashington DC. 1973

Santoso I, Roy Kumar S,. 2004. Pengaruh Penggunaan Bottom Ash Terhadap Karakteristik Campuran aspa/ Beto. Dimensi Teknik Sipil Volume 6 Nomor 1

Sugiri. S. 2005. Pengaruh Terak Nikel Berdasarkan Uji Sifat Kimia dan Fisik untuk Campuran Beton Kinerja Tinggi. Departemen Teknik Sipil, Institut Teknologi Bandung. Yoga. P, Heri T. Putranto. 2007. Coal Fly Ash Conversion to Zeolite for Removal of Chromium and
Nickel from Waste Water. 